medRxiv preprint doi: https://doi.org/10.1101/2020.07.28.20164038; this version posted February 28, 2021. The copyright holder for this preprint (which was not certified by peer review) is the author/funder, who has granted medRxiv a license to display the preprint in perpetuity.

It is made available under a CC-BY-NC 4.0 International license .

\title{
Initial evaluation of a mobile SARS-CoV-2 RT-LAMP testing strategy
}

Christina M. Newman ${ }^{1 *}$, Mitchell D. Ramuta ${ }^{1 *}$, Matthew T. McLaughlin ${ }^{1}$, Roger W. Wiseman ${ }^{1}$, Julie A. Karl $^{1}$, Dawn M. Dudley ${ }^{1}$, Miranda R. Stauss ${ }^{3}$, Robert J. Maddox ${ }^{3}$, Andrea M. Weiler ${ }^{3}$, Mason I. Bliss ${ }^{2}$, Katrina N. Fauser ${ }^{3}$, Luis A. Haddock III², Cecilia G. Shortreed ${ }^{1}$, Amelia K. Haj ${ }^{1}$, Molly A. Accola ${ }^{4}$, Anna S. Heffron ${ }^{1}$, Hailey E. Bussan ${ }^{1}$, Matthew R. Reynolds ${ }^{2,3}$, Olivia E. Harwood ${ }^{1}$, Ryan V. Moriarty ${ }^{1}$, Laurel M. Stewart ${ }^{1}$, Chelsea M. Crooks ${ }^{2}$, Trent M. Prall ${ }^{1}$, Emma K. Neumann ${ }^{1}$, Elizabeth D. Somsen ${ }^{1}$, Corrie B. Burmeister ${ }^{1}$, Kristi L. Hall ${ }^{1}$, William M. Rehrauer ${ }^{1,4}$, Thomas C. Friedrich ${ }^{2,3}$, Shelby L. O'Connor ${ }^{1,3}$, David H. O'Connor ${ }^{1,3}$

Author Affiliations:

Pathology and Laboratory Medicine, School of Medicine and Public Health, University of WisconsinMadison, Madison, WI, USA ${ }^{1}$

Pathobiological Sciences, School of Veterinary Medicine, University of Wisconsin-Madison, Madison, WI, USA ${ }^{2}$

Wisconsin National Primate Research Center, Madison, WI, USA ${ }^{3}$

University of Wisconsin Hospitals and Clinics, Madison, WI, USA ${ }^{4}$

${ }^{*}$ These authors contributed equally to this work.

No. text pages: 26, No. tables and figures: 4 tables, 3 figures, 1 supplemental table

Running head: RT-LAMP surveillance for SARS-CoV-2

Funding and support: NIH RADx (3 U54 EB027690-0S1), NIH P51 (OD011106 to WNPRC), RFIP (RR15459-01 and RR020141-01 to WNPRC), WARF COVID-19 Challenge grant, NIH T32 (A|007414 to A.S.H. and C.M.C.)

Conflicts of interest: C.M.N., D.M.D, A.M.W., D.H.O., and T.C.F. provided consulting services to Salus Discovery LLC. D.H.O. is also a consultant for Batelle.

Correspondence: David H. O’Connor, 555 Science Dr, Madison, WI 53711 Phone: (608) 890-0845, Fax (608) 265-8084, Email: dhoconno@wisc.edu 
medRxiv preprint doi: https://doi.org/10.1101/2020.07.28.20164038; this version posted February 28, 2021. The copyright holder for this preprint (which was not certified by peer review) is the author/funder, who has granted medRxiv a license to display the preprint in perpetuity.

It is made available under a CC-BY-NC 4.0 International license.

\section{Abstract (220 of 220 words)}

29 Severe acute respiratory syndrome coronavirus 2 (SARS-CoV-2) control in the United States remains

30 hampered, in part, by testing limitations. We evaluated a simple, outdoor, mobile, colorimetric reverse

31 transcription loop-mediated isothermal amplification (RT-LAMP) assay workflow where self-collected saliva is tested for SARS-CoV-2 RNA. From July 16 to November 19, 2020, 4,704 surveillance samples were collected from volunteers and tested for SARS-CoV-2 at 5 sites. A total of 21 samples tested positive for SARS-CoV-2 by RT-LAMP; 12 were confirmed positive by subsequent quantitative reversetranscription polymerase chain reaction (qRT-PCR) testing, while 8 were negative for SARS-CoV-2 RNA, and 1 could not be confirmed because the donor did not consent to further molecular testing. We estimated the RT-LAMP assay's false-negative rate from July 16 to September 17, 2020 by pooling residual heat-inactivated saliva that was unambiguously negative by RT-LAMP into groups of 6 or less and testing for SARS-CoV-2 RNA by qRT-PCR. We observed a 98.8\% concordance between the RTLAMP and qRT-PCR assays, with only 5 of 421 RT-LAMP negative pools (2,493 samples) testing positive in the more sensitive qRT-PCR assay. Overall, we demonstrate a rapid testing method that can be implemented outside the traditional laboratory setting by individuals with basic molecular biology skills and can effectively identify asymptomatic individuals who would not typically meet the criteria for symptom-based testing modalities. 
medRxiv preprint doi: https://doi.org/10.1101/2020.07.28.20164038; this version posted February 28, 2021. The copyright holder for this preprint (which was not certified by peer review) is the author/funder, who has granted medRxiv a license to display the preprint in perpetuity.

It is made available under a CC-BY-NC 4.0 International license .

0

\section{Introduction}

More than 340,000,000 severe acute respiratory syndrome coronavirus 2 (SARS-CoV-2) diagnostic tests have been performed in the United States as of February 22, 2021, yet it is estimated that $80-95 \%$ of infected individuals are not tested ${ }^{1,2}$. The availability of diagnostic testing for population surveillance around the United States has been limited because of testing supply shortages and guidelines set by public health officials ${ }^{3,4}$. Multiple studies have shown that asymptomatic and presymptomatic individuals infected with SARS-CoV-2 can be as infectious as symptomatic individuals ${ }^{5-9}$, with recent estimates of up to $59 \%$ of transmission coming from asymptomatic or presymptomatic individuals ${ }^{10}$. Virological assessments of SARS-CoV-2-positive individuals and coronavirus disease 2019 (COVID19) patients further support the reports of asymptomatic transmission, identifying no significant differences in viral loads found in the upper respiratory tracts of asymptomatic and symptomatic individuals ${ }^{5,7,11-13}$. Furthermore, Arons et al. (2020) demonstrated that positive viral cultures can be isolated from presymptomatic patients up to 6 days before the onset of symptoms ${ }^{5}$.

Delays in reporting test results can prevent timely isolation of infected individuals. Most current testing programs fail to identify and efficiently notify infected individuals. Since transmission can occur before symptoms manifest, reporting delays create a major barrier to safely returning to workplaces and schools ${ }^{14}$. Therefore, there remains an urgent need for rapid tests that identify presymptomatic and asymptomatic individuals while conserving diagnostic testing reagents. Non-diagnostic point-of-care (POC) testing, used in conjunction with the current clinical diagnostic testing regimen, may improve our ability to identify infectious individuals and limit their exposure to others while they are most contagious and conserve clinical diagnostic tests for those who require confirmatory testing. Incorporating active surveillance using POC tests as part of mitigation strategies for reopening K-12 schools could play an integral role in reducing SARS-CoV-2 transmission among students, teachers and staff members, families, and the surrounding community ${ }^{15,16}$.

1 Loop-mediated isothermal amplification (LAMP) is a low-cost method for rapid target-specific detection 
medRxiv preprint doi: https://doi.org/10.1101/2020.07.28.20164038; this version posted February 28, 2021. The copyright holder for this preprint (which was not certified by peer review) is the author/funder, who has granted medRxiv a license to display the preprint in perpetuity.

It is made available under a CC-BY-NC 4.0 International license .

82 of nucleic acids ${ }^{17}$. LAMP has long been used as an alternative to gold-standard quantitative reverse

83 transcription polymerase chain reaction (qRT-PCR) to surveil populations for a variety of pathogens,

84 especially in resource-limited settings ${ }^{18-22}$. Reverse transcription LAMP (RT-LAMP) assays have

85 recently been developed for rapid SARS-CoV-2 testing ${ }^{23-29}$. RT-LAMP is an appealing candidate for

86 POC SARS-CoV-2 testing because it is inexpensive, circumvents supply shortages by relying on

87 different reagents than current diagnostic tests, requires minimal sample processing, and can be

88 deployed outside of traditional laboratory settings. Recently, a number of studies have shown the

89 correlation between the presence of virus in saliva and nasopharyngeal swabs, demonstrating that

90 saliva specimens are a valid and reliable alternative to nasopharyngeal swab specimens for SARS-

91 CoV-2 testing ${ }^{30-35}$. Saliva specimen self-collection is noninvasive, can be done at home, does not

92 require swabs or personal protective equipment, and limits direct contact between test operators and

93 testing populations. Here we describe our experience implementing a simple, rapid-turnaround, mobile,

94 non-diagnostic SARS-CoV-2 testing workflow combining self-collected saliva and RT-LAMP in

95 volunteers without symptoms of SARS-CoV-2 infection. Individuals were strongly encouraged to isolate

96 and obtain follow-up diagnostic testing after receiving a positive result by RT-LAMP. This addresses a

97 key knowledge gap of how on-site RT-LAMP testing performs in real-world conditions, since virtually all

98 previous studies have only evaluated SARS-CoV-2 RT-LAMP in well-equipped molecular biology

99 laboratories.

100

$101 \quad$ Materials and Methods

102 POC testing sites

103 To begin operating voluntary POC testing, we developed a system of color-coded storage bins for 104 equipment and supplies, as well as assembled folding tables, chairs, extension cords, and coolers that 105 could be easily decontaminated and packed to fit in a Dodge Caravan (FCA US LLC., Auburn Hills, MI) 106 or other, similarly sized minivan for transportation between testing sites and our base laboratory facility. 107 On July 16, 2020, we launched our first mobile POC testing sites which ultimately expanded over 18 108 weeks to include two workplaces, two K-12 schools, and an athletics program (Suppl. Table 1). With 
medRxiv preprint doi: https://doi.org/10.1101/2020.07.28.20164038; this version posted February 28, 2021. The copyright holder for this preprint (which was not certified by peer review) is the author/funder, who has granted medRxiv a license to display the preprint in perpetuity.

It is made available under a CC-BY-NC 4.0 International license .

109 the exception of the athletics program, sites were initially outdoors, sometimes under an overhang, but 110 otherwise open to the environment. The athletics site was a climate-controlled, indoor practice field. At 111 all sites, equipment and reagents were transported by minivan and surfaces were disinfected during 112 assembly, breakdown, and frequently throughout testing. Participant consenting and volunteer sample 113 collection were performed on-site but separated from the sample preparation and assay areas (most 114 commonly on the other side of the building). In an effort to limit contamination, each assay area was set 115 up with three separate folding tables: (1) sample heat-inactivation and preparation, (2) preparation of 116 RT-LAMP reagents and assay set-up, and (3) RT-LAMP incubation and imaging. Individuals responsible for sample inactivation and performing assays wore appropriate personal protective equipment (PPE) including N95 face masks, face shields or safety glasses, disposable lab coats, and double gloves. In anticipation of wet and cold fall weather, by September 2020, assay workspaces were transitioned to biosafety hoods in a vacant indoor laboratory space for several POC testing locations. In October 2020, we received IRB approval for obtaining consent for repeat SARS-CoV-2 testing. This allowed us to transition away from consenting participants at each testing time point and instead allowed each enrolled participant to consent once regardless of the number of times they supplied a sample. Following reports that SARS-CoV-2 RNA is stable in saliva at room temperature for prolonged periods ${ }^{36}$, we also transitioned away from in-person sample collection at some of the testing sites and instead distributed self-collection take-home kits for drop off at designated locations for same day processing.

\section{Sample collection and preparation}

130 We obtained approval from the University of Wisconsin-Madison Institutional Review Board (\#20201310855 and \#2020-1142). Participants were advised to avoid eating, or drinking anything except for water, 132 for 30 minutes prior to providing a sample. After providing informed consent, volunteers self-collected at 133 least $50 \mu \mathrm{l}$ of saliva in a $1.5 \mathrm{ml}$ "safe-lock" microcentrifuge tube using a $1000 \mu \mathrm{l}$ unfiltered pipette tip to 134 funnel the specimen into the tube. Each volunteer disinfected the outside of the tube with a pre135 moistened disinfectant wipe. Samples collected in-person were typically processed within 3 hours of 
medRxiv preprint doi: https://doi.org/10.1101/2020.07.28.20164038; this version posted February 28, 2021. The copyright holder for this preprint (which was not certified by peer review) is the author/funder, who has granted medRxiv a license to display the preprint in perpetuity.

It is made available under a CC-BY-NC 4.0 International license .

collection through our RT-LAMP mobile testing workflow, while samples collected using take-home kits were typically processed within 30 hours (Figure 1). Samples were first incubated in a heat block at $65^{\circ} \mathrm{C}$ for 30 minutes to inactivate SARS-CoV-2 ${ }^{37}$ and then incubated in another preset heat block at $98^{\circ} \mathrm{C}$ for 3 minutes to improve nucleic acid detection and inactivate salivary enzymes ${ }^{38}$. The inactivated saliva was then centrifuged for 2 minutes in a benchtop microcentrifuge. Fifty microliters of the saliva supernatant were then added to $50 \mu \mathrm{l}$ of $1 \mathrm{x}$ phosphate buffered saline, $\mathrm{pH} 7.4$ (1x PBS).

\section{RT-LAMP reactions}

Three microliters of the saliva/PBS mixture for each sample was added in duplicate to $17 \mu \mathrm{l}$ of a colorimetric RT-LAMP reaction mix containing WarmStart colorimetric LAMP mastermix (NEB, catalogue\# M1800), water, and a set of six SARS-CoV-2-specific RT-LAMP primers designed against the $\mathrm{N}$ gene ${ }^{38}$. The SARS-CoV-2 RT-LAMP primer set was previously designed by Broughton et al. and is currently used in an FDA emergency use authorized (EUA) COVID-19 test by Color Genomics (Table 1) ${ }^{39,40}$. Reactions were incubated for 30 minutes at $65^{\circ} \mathrm{C}$. A smartphone or tablet was used to record images of each reaction before $($ time $=0$ ) and after the incubation period (time $=30)$. A color change from pink/orange to yellow in at least 1 of 2 replicates was scored relative to gamma-irradiated SARSCoV-2 (irSARS-CoV-2, BEI Resources, Manassas, VA) that was directly added to RT-LAMP reactions as a positive control in each batch of reactions at concentrations ranging from $220-3,333$ copies $/ \mu$ l $\left(2.2 \times 10^{5}-3.33 \times 10^{6}\right.$ copies $\left./ \mathrm{ml}\right)$. irSARS-CoV-2 was diluted and aliquoted as ready-to-run positive control standards and stored at $-80^{\circ} \mathrm{C}$. On the day of testing, the positive controls were removed from the freezer and stored on ice at POC sites. Individuals whose samples were recorded as potentially positive for SARS-CoV-2 by RT-LAMP were contacted by an infectious disease clinician in accordance with the IRB protocol and urged to obtain a clinical diagnostic test to confirm findings and self-isolate in accordance with public health recommendations.

Limit of detection (LOD) estimation using contrived saliva samples

To estimate the limit of detection of the RT-LAMP assay, contrived positive saliva samples were 
medRxiv preprint doi: https://doi.org/10.1101/2020.07.28.20164038; this version posted February 28, 2021. The copyright holder for this preprint (which was not certified by peer review) is the author/funder, who has granted medRxiv a license to display the preprint in perpetuity.

It is made available under a CC-BY-NC 4.0 International license .

163 prepared by adding irSARS-CoV-2 diluted from $1 \times 10^{4}-10$ copies $/ \mu l\left(1 \times 10^{7}-1 \times 10^{4}\right.$ copies $\left./ \mathrm{ml}\right)$ or from $1645 \times 10^{4}-50$ copies $/ \mu l\left(5 \times 10^{7}-5 \times 10^{4}\right.$ copies $\left./ \mathrm{ml}\right)$ directly into unaltered saliva collected from a total of 25 165 SARS-CoV-2-negative individuals. Dilutions were based on two independent, in-house qRT-PCR 166 experiments showing that the ir-SARS-CoV-2 stock concentration ranged from $7.89 \times 10^{6}-8.23 \times 10^{6}$ 167 copies $/ \mu \mathrm{l}\left(7.89 \times 10^{9}-8.23 \times 10^{9}\right.$ copies $\left./ \mathrm{ml}\right)$. In two RT-LAMP experiments, four serial dilutions of irSARS168 CoV-2 were prepared for each saliva sample in duplicate. RT-LAMP reactions were set up as described 169 previously. Negative controls consisting of $1 \times$ PBS and positive controls consisting of $1 \times 10^{4}$ copies/ $\mu$ l $170\left(1 \times 10^{7}\right.$ copies $\left./ \mathrm{ml}\right)$ irSARS-CoV-2 in water were also prepared in duplicate. Reactions were called 171 positive if a color change from pre-amplification to post-amplification occurred in at least 1 of 2 replicates that was consistent with that of the positive controls.

174 Limit of detection (LOD) estimation using clinical samples

175 De-identified discard saliva samples from 38 SARS-CoV-2-positive patients were provided by the 176 University of Wisconsin Hospitals and Clinics (UWHC) for evaluation of RT-LAMP performance with 177 known positive saliva samples. Clinical saliva samples were originally collected and stored at $4^{\circ} \mathrm{C}$ for up 178 to 4 weeks prior to assessment by RT-LAMP. Additional 10-fold and 100-fold dilutions were prepared 179 for 13 of the samples in saliva collected from a negative volunteer. Clinical samples and dilutions were 180 prepared as described previously except that 20-50 $\mu$ l of heat-inactivated sample, dependent on total 181 sample volume, was added to an equal volume of 1x PBS in a clean $1.5 \mathrm{ml}$ screw-top tube and pipetted 182 gently to mix. For each sample, $3 \mu \mathrm{l}$ was then added to duplicate colorimetric RT-LAMP reactions. 183 Negative and positive control reactions (described previously) were also prepared in duplicate except 184 that saliva collected from a negative volunteer was used as the negative control for these reactions. 185 RT-LAMP reactions were prepared and images collected as described previously.

187 Quantitative RT-PCR

188 POC samples 
medRxiv preprint doi: https://doi.org/10.1101/2020.07.28.20164038; this version posted February 28, 2021. The copyright holder for this preprint (which was not certified by peer review) is the author/funder, who has granted medRxiv a license to display the preprint in perpetuity.

It is made available under a CC-BY-NC 4.0 International license .

We measured vRNA concentration using sensitive qRT-PCR in a subset of the inactivated saliva samples described above after initial evaluation using RT-LAMP. Saliva samples that were negative for SARS-CoV-2 by RT-LAMP were pooled into groups of 6 or fewer for qRT-PCR to balance cost effectiveness with reasonable estimated detection sensitivity. Ten additional, individual RT-LAMPnegative samples were submitted as negative controls alongside samples identified as positive by RTLAMP. Saliva samples that were identified as positive for SARS-CoV-2 by RT-LAMP were tested by qRT-PCR individually to estimate our POC LOD. RNA was isolated from up to $150 \mu$ saliva and combined with an equivalent volume of nuclease-free water using the Viral Total Nucleic Acid kit for the Maxwell RSC instrument (Promega, Madison, WI) following the manufacturer's instructions. Viral load quantification was performed using a sensitive qRT-PCR assay developed by the CDC to detect SARSCoV-2 (specifically the N1 assay) and commercially available from IDT (Coralville, IA). The assay was run on a LightCycler 96 or LC480 instrument (Roche, Indianapolis, IN) using the Taqman Fast Virus 1step Master Mix enzyme (Thermo Fisher, Waltham, MA). The limit of detection of this assay is estimated to be 0.2 genome equivalents $/ \mu$ l (200 genome equivalents $/ \mathrm{ml}$ ) saliva. To determine the vRNA load, samples were interpolated onto a standard curve consisting of serial 10-fold dilutions of in vitro transcribed SARS-CoV-2 N gene RNA kindly provided by Nathan Grubaugh (Yale University) and described by Dudley et al. ${ }^{35}$.

\section{Clinical samples}

qRT-PCR was performed using the conditions described above for each of the 38 SARS-CoV-2 positive saliva samples individually; however, sample volume limitations required that for some samples, only $100 \mu \mathrm{l}$ saliva was combined with $100 \mu \mathrm{l}$ of nuclease-free water prior to RNA isolation. In addition, sample UWHC3 contained a lower volume than the remaining 37 samples so $50 \mu$ saliva was combined with $50 \mu \mathrm{l}$ nuclease-free water and used for RNA isolation as described previously. Viral loads in copies per microliter and corresponding cycle threshold numbers (Ct) are reported in Table 2.

\section{Results}


medRxiv preprint doi: https://doi.org/10.1101/2020.07.28.20164038; this version posted February 28, 2021. The copyright holder for this preprint (which was not certified by peer review) is the author/funder, who has granted medRxiv a license to display the preprint in perpetuity.

It is made available under a CC-BY-NC 4.0 International license .

\section{LOD estimation using contrived saliva samples}

217 We assessed the LOD for minimally processed saliva samples collected from 25 volunteers over two 218 RT-LAMP experiments using irSARS-CoV-2 spiked into negative saliva samples (Figure 2A and 2B). In 219 our first experiment (S1-S3), we detected irSARS-CoV-2 in at least 1 of 2 replicates at $1 \times 10^{2}$ copies/ $\mu$ l $220\left(1 \times 10^{5}\right.$ copies $\left./ \mathrm{ml}\right)$ in all 3 samples (Figure $\left.2 \mathrm{~A}\right)$. In our second experiment (S4-S25), we detected 221 irSARS-CoV-2 by RT-LAMP in $2 / 2$ replicates at $5 \times 10^{4}$ copies $/ \mu l\left(5 \times 10^{7}\right.$ copies $\left./ \mathrm{ml}\right)$ for $95 \%$ of samples, 222 at $5 \times 10^{3}$ copies $/ \mu l\left(5 \times 10^{6}\right.$ copies $\left./ \mathrm{ml}\right)$ for $62 \%$ of samples, and at 500 copies $/ \mu l\left(5 \times 10^{5} \mathrm{copies} / \mathrm{ml}\right)$ for $10 \%$ 223 of samples. When we included samples called positive in at least 1 of 2 replicates (see Methods), the 224 percentage of contrived samples positive by RT-LAMP at each of the aforementioned dilutions were 225 100\%, 90\%, and 33.3\% respectively (Figure 2B). One sample was omitted from the analysis because it 226 turned yellow before the RT-LAMP reaction incubation began and was therefore uninterpretable. 227 Because in POC testing we defined a positive RT-LAMP result as an observed post-incubation color 228 change to yellow in at least 1 replicate, these results suggested that our $90 \%$ LOD is between $1 \times 10^{2}$ and $5 \times 10^{3}$ copies $/ \mu \mathrm{l}\left(1 \times 10^{5}-5 \times 10^{6}\right.$ copies $\left./ \mathrm{ml}\right)$.

LOD estimation using clinical samples

To assess the performance of SARS-CoV-2 RT-LAMP in known SARS-CoV-2 positive saliva samples as opposed to contrived positive samples, we acquired deidentified, discarded saliva samples collected from 38 patients with laboratory confirmed SARS-CoV-2 from UWHC. Nineteen of 38 undiluted saliva samples were positive for SARS-CoV-2 in $2 / 2$ replicates by RT-LAMP (Figure 3; Table 2). Two additional samples were positive in 1 of 2 replicates. Quantitative RT-PCR data showed that the viral RNA (vRNA) loads of the positive samples ranged from 131 copies $/ \mu$ to $5.7 \times 10^{4}$ copies/ $\mu l\left(1.31 \times 10^{5}\right.$ $5.71 \times 10^{7}$ copies $/ \mathrm{ml}$ ) which was consistent with our LOD range for contrived samples (Table 3). Furthermore, for the 13 samples diluted 10-fold and 100-fold, detection decreased with increasing 
medRxiv preprint doi: https://doi.org/10.1101/2020.07.28.20164038; this version posted February 28, 2021. The copyright holder for this preprint (which was not certified by peer review) is the author/funder, who has granted medRxiv a license to display the preprint in perpetuity.

It is made available under a CC-BY-NC 4.0 International license .

243 From July 16 to November 19, 2020, SARS-CoV-2 RT-LAMP was used to test a total of 4,704 samples

244 collected from 5 locations. Participants were enrolled into the study regardless of their SARS-CoV-2 245 symptom status on the day of testing. Seventy-one percent of the samples were obtained from 246 individuals at two research facilities, $11 \%$ from two K-12 schools, and $18 \%$ from an athletics program 247 (Supplemental Table 1). A total of 21 samples were identified as positive for SARS-CoV-2 by RT-LAMP 248 based on a colorimetric change from pink/orange to yellow in at least 1 of 2 sample replicates. Similar 249 to our experience with our contrived LOD samples, about $0.40 \%(19 / 4,704)$ of samples collected during 250 POC testing exhibited a color change to yellow prior to RT-LAMP assay amplification and were 251 therefore uninterpretable. Follow up qRT-PCR testing was conducted on each sample that appeared 252 positive after the 30 minute amplification reaction throughout the study to determine vRNA load. Twelve 253 of the 21 samples called positive in RT-LAMP had detectable SARS-CoV-2 RNA by qRT-PCR. Viral 254 RNA loads of these samples ranged from 8.58 copies $/ \mu l$ to $3.62 \times 10^{5}$ copies $/ \mu l\left(8.58 \times 10^{3} \mathrm{copies} / \mathrm{ml}-\right.$ $2553.62 \times 10^{8}$ copies $\left./ \mathrm{ml}\right)$ with a median of 504.5 copies $/ \mu l\left(5.04 \times 10^{5}\right.$ copies $\left./ \mathrm{ml}\right)($ Table 4$)$. Eight of the saliva samples identified as positive by RT-LAMP were negative by qRT-PCR, suggesting that they were false-positive RT-LAMP results. One RT-LAMP-positive sample was not tested by qRT-PCR because the participant did not consent to additional molecular testing. For volunteers who consented to additional research testing from July 16 to September 17, qRT-PCR testing was conducted for pools of 6 or fewer for all residual, heat-inactivated samples that appeared unambiguously negative by RTLAMP. A total of 421 RT-LAMP-negative pools (2,493 samples) were tested to estimate the number of SARS-CoV-2-positive samples missed by RT-LAMP. Quantitative RT-PCR detected SARS-CoV-2 nucleic acids in 5 pools of RT-LAMP-negative samples. Four out of five of the positive pools contained levels of SARS-CoV-2 that were below the estimated LOD range for RT-LAMP using crude samples with vRNA load estimates of $0.236,0.444,0.460,37.5$, and 142 copies/ $\mu$ l $\left(236,444,460,3.75 \times 10^{4}\right.$, and $1.42 \times 10^{5}$ copies $\left./ \mathrm{ml}\right)$. Taken together, the low prevalence of SARS-CoV-2 in our volunteer testing population $(0.36 \%$, including RT-LAMP-negative, qRT-PCR-positive pools) and the low vRNA load of 268 pools positive by follow-up qRT-PCR, suggest that these 5 pools likely contained only a single positive sample each and suggests a false-negative rate of $0.02 \%(5 / 2,493)$ (Table 4$)$. 
medRxiv preprint doi: https://doi.org/10.1101/2020.07.28.20164038; this version posted February 28, 2021. The copyright holder for this preprint (which was not certified by peer review) is the author/funder, who has granted medRxiv a license to display the preprint in perpetuity.

It is made available under a CC-BY-NC 4.0 International license .

271 Discussion

272 Strategic surveillance testing of asymptomatic individuals has been suggested as an important 273 mitigation strategy for places at high risk for close contact, indoor SARS-CoV-2 transmission: schools, 274 workplaces, places of worship, and prisons, among others. Decentralized, mobile RT-LAMP-based 275 POC testing workflows can provide same-day results which can enable people with potential SARS276 CoV-2 infections to quickly self-isolate and then obtain confirmatory diagnostic testing. The low per-test cost (approximately $\$ 7$ per sample tested in duplicate) allows for repeated testing to identify incident infections and reduce the duration of a potentially infected individual's exposure to others. While RTLAMP is not as sensitive as diagnostic qRT-PCR tests in laboratory testing, qRT-PCR tests require centralized labs, which in turn leads to lengthy turnaround times. Over a period of 18 weeks, we performed 4,704 SARS-CoV-2 tests across 5 sites using a simple, saliva-based, direct RT-LAMP assay. This work demonstrates the scalability of decentralized, mobile RT-LAMP-based testing and addresses a key knowledge gap of how POC RT-LAMP testing performs outside of well-equipped molecular biology laboratories.

Our initial experiments using direct RT-LAMP with contrived saliva samples from a total of 25 donors demonstrated a LOD that ranged from $1 \times 10^{2}$ copies/ $\mu$ l (100\% in at least 1 replicate for S1-S3) to $5 \times 10^{3}$ copies/ $\mu \mathrm{l}(90 \%$ in at least one replicate for S4-S25). Taken together, these data suggest that the actual LOD for RT-LAMP without RNA isolation may be dependent on the individual sample due to heterogeneity of saliva $\mathrm{pH}$ and composition ${ }^{41-43}$. Overall, the RT-LAMP results for 38 clinical saliva samples obtained from SARS-CoV-2-positive individuals at the UWHC, were consistent with those for 292 the contrived samples. We recognize that more clinical samples are required for a comprehensive 293 clinical validation, but the LOD observed in clinical samples is further supported by the low vRNA loads 294 obtained from qRT-PCR-confirmed SARS-CoV-2-positive samples identified in our volunteer population 295 (Table 4). The performance of our RT-LAMP POC testing workflow demonstrates that inexpensive, 296 mobile testing can be successfully performed outdoors or in other non-traditional laboratory settings to 
medRxiv preprint doi: https://doi.org/10.1101/2020.07.28.20164038; this version posted February 28, 2021. The copyright holder for this preprint (which was not certified by peer review) is the author/funder, who has granted medRxiv a license to display the preprint in perpetuity.

It is made available under a CC-BY-NC 4.0 International license .

identify SARS-CoV-2-positive individuals regardless of whether or not symptoms are present. Our observed SARS-CoV-2 RT-LAMP positivity rate was $0.25 \%(12 / 4,704)$ for samples confirmed by followup qRT-PCR. Interestingly, the positivity rate of $0.25 \%$ in our volunteer population was lower than expected given the disease activity in our region during this period of time was listed as "critically high", particularly between September 1 and November 19, 2020 when the county had a 5.42\% positivity rate $(19,031 \text { positive tests out of } 350,722)^{44,45}$. The low positivity rate in our volunteer population may be partly explained by the fact that $71 \%$ of tested saliva specimens came from two research facilities where mask wearing and physical distancing guidelines were implemented early in the pandemic and followed relatively stringently (Supplemental Table 1). Volunteers for nonsymptomatic research testing might also have a different risk profile from the overall population.

Potential drawbacks of colorimetric RT-LAMP-based surveillance for SARS-CoV-2 as described here include the fact that minimally-processed saliva can result in variable reaction color change without the presence of the target RNA. However, modifications of RT-LAMP-based SARS-CoV-2 assays to reduce saliva sample variability, improve result ambiguity, and increase throughput have recently been reported elsewhere and may improve the implementation of RT-LAMP-based assays for POC use ${ }^{46-50}$. In addition, we relied on a manual RT-LAMP format during POC testing. Reading assays "by eye" inevitably results in a somewhat subjective determination of positives. Reducing false-positive results in our POC volunteer populations required consistent use of duplicate reactions for each individual, which reduced assay throughput and increased the per-sample cost. Furthermore, the testing landscape changed dramatically during the months we performed RT-LAMP testing. The first non-instrumented antigen test, the Abbott BinaxNOW COVID-19 Ag CARD, received FDA EUA approval in the United States on August 26, $2020{ }^{51}$. While the sensitivity of RT-LAMP is broadly comparable to the Abbott BinaxNOW antigen test (reported as $1.6 \times 10^{4}-4.3 \times 10^{4}$ vRNA copies; Ct 30.3-28.8), because the former is technically straightforward and can be used as a SARS-CoV-2 diagnostic at testing sites operating under a Clinical Laboratory Improvement Amendments (CLIA) waiver, it is likely a better choice for rapid turnaround, on-site testing in most circumstances ${ }^{52}$. However, even with the existence of antigen 
medRxiv preprint doi: https://doi.org/10.1101/2020.07.28.20164038; this version posted February 28, 2021. The copyright holder for this preprint (which was not certified by peer review) is the author/funder, who has granted medRxiv a license to display the preprint in perpetuity.

It is made available under a CC-BY-NC 4.0 International license .

324

tests, RT-LAMP surveillance programs still have a place as part of a comprehensive SARS-CoV-2 risk mitigation strategy, especially in areas where access to antigen tests is limited.

There are advantages to continuing saliva-based RT-LAMP surveillance testing. Importantly, the supply of diagnostic antigen tests remains tightly constrained, and in the United States, these tests are available only through government contracts. Widespread testing of individuals without symptoms with such a scarce resource may not be a wise use of these limited tests. Furthermore, recent studies have shown that antigen test performance may differ between asymptomatic and symptomatic populations. Compared to qRT-PCR, the sensitivity of FDA-approved antigen tests, BinaxNOW and the Quidel Sofia SARS Antigen Fluorescent Immunoassay, were $35 \%$ and $41 \%$ in asymptomatic individuals and $64 \%$ and $80 \%$ in symptomatic individuals, respectively ${ }^{53,54}$. BinaxNOW is currently only approved for use in symptomatic individuals, within 7 days of symptom onset, and samples are required to be tested within an hour of collection ${ }^{55}$. In contrast, RT-LAMP reagents do not require a government contract and can be acquired readily from commercial and non-commercial sources, and they can also be used more flexibly for surveillance purposes because RT-LAMP is not limited to use in symptomatic individuals ${ }^{56}$. Additionally, user acceptance of testing may also favor saliva-based RT-LAMP as it is less invasive than nasal swab-based tests. While an individual BinaxNOW test is rapid, performing several tests during a single day could cumulatively take as long as processing a batch of tests by RT-LAMP. For these reasons, RT-LAMP may still be the preferred testing method to incorporate into a local program. In Madison, WI, two local schools have implemented RT-LAMP surveillance programs modeled on the program described here. Implementation of each program required approximately 50 hours of hands-on training by our group. School staff were trained in adherence to regulations pertaining to non-diagnostic testing and to competently perform RT-LAMP assays. Each school also needed time and resources to acquire the modest lab infrastructure necessary to perform RT-LAMP. In addition, a larger saliva-based RT-LAMP surveillance program has been successfully implemented in school districts in the greater Chicago suburbs ${ }^{57,58}$. 
medRxiv preprint doi: https://doi.org/10.1101/2020.07.28.20164038; this version posted February 28, 2021. The copyright holder for this preprint (which was not certified by peer review) is the author/funder, who has granted medRxiv a license to display the preprint in perpetuity.

It is made available under a CC-BY-NC 4.0 International license .

A looming question for both RT-LAMP and antigen testing programs is whether the real-world effectiveness of frequently testing individuals without symptoms mirrors the theoretical benefits. Several important considerations that we factored into the design of RT-LAMP testing remain true: nonsymptomatic individuals account for up to $59 \%$ of all transmission (24\% asymptomatic and $35 \%$ presymptomatic); low-sensitivity tests are able to effectively identify those with high levels of virus shedding, and individuals with high viral loads are likely to be responsible for a significant fraction of onward community transmission; and the duration of peak infectiousness is short, so lengthy lags in reporting test results could miss a critical window of high transmissibility ${ }^{10,59}$. Conversely, high-quality, exceptionally well-resourced testing programs such as those at the White House and among intercollegiate athletic programs have failed to stop outbreaks ${ }^{60}$. The latter deserves special note: outbreaks in these programs occurred in spite of $100 \%$ adherence to daily testing. Data from daily sampling of individuals with incident SARS-CoV-2 infection suggests that the mean duration of time from infection to peak viral shedding is approximately three days, but some individuals potentially reach peak viral shedding in under one day ${ }^{61}$. The potential for an extremely rapid increase in viral load, which likely parallels shedding of infectious virus, means that in some cases, even daily testing might be insufficient to protect a community from someone who is newly infected.

Perhaps more importantly, the benefit of frequent testing of individuals without symptoms with RT-

LAMP or other assays may be substantially undermined by risk disinhibition. When people are tested frequently, they may both underestimate their own risk of becoming infected in the interval between tests and overestimate the possibility that their similarly tested contacts are uninfected; anecdotal evidence of this phenomenon is perhaps most vividly seen in the September 26, 2020 White House Rose Garden reception for Justice Amy Coney Barrett, in which many attendees were photographed not wearing masks nor following guidelines for physical distancing ${ }^{62}$. If infections among people without symptoms are rare ( $0.4 \%$ of tests in this study, when combining RT-LAMP and pooled qRT-PCR positives), but $10 \%$ of the tested population views testing as license for increased risk-tasking, is frequent testing of symptomless people a net positive? Appropriate messaging to the community is 
medRxiv preprint doi: https://doi.org/10.1101/2020.07.28.20164038; this version posted February 28, 2021. The copyright holder for this preprint (which was not certified by peer review) is the author/funder, who has granted medRxiv a license to display the preprint in perpetuity.

It is made available under a CC-BY-NC 4.0 International license .

essential with any testing program to ensure the population understands the meaning of a test result.

379 Such issues will require an optimization of messaging to mitigate the impact of risk disinhibition to the 380 extent possible.

Ultimately, this study provides proof of concept and guidance for how decentralized rapid testing could be implemented in a mobile testing scenario, which may be especially useful in resource-limited settings. Despite the caveats presented above, we identified 12 SARS-CoV-2-positive individuals and likely prevented onward transmission from those individuals who otherwise would not know they were positive. Rapid tests, although less sensitive than qRT-PCR, have shorter turnaround times and could bridge the gap between SARS-CoV-2 surveillance and diagnostic testing. POC testing can be effective for identifying asymptomatic individuals but must be used in conjunction with appropriate messaging and other mitigation strategies to effectively reduce SARS-CoV-2 transmission.

\section{Acknowledgments}

392 This work was made possible by financial support through NIH Rapid Acceleration of Diagnostics (3 U54 EB027690-02S1). Additional funding was provided in part by the office of the director, National Institutes of Health, under award number P51OD011106 to the Wisconsin National Primate Research Center (WNPRC), University of Wisconsin-Madison. This research was conducted in part at a facility constructed with support from Research Facilities Improvement Program grant numbers RR15459-01 and RR020141-01. The content is solely the responsibility of the authors and does not necessarily represent the official views of the National Institutes of Health. Additional funding was provided by the Wisconsin Alumni Research Foundation (WARF) COVID-19 Challenge. A.S.H. and C.M.C. have been supported by the National Institutes of Health National Research Service Award T32 Al007414. We are grateful for the assistance of both the University of Wisconsin Institutional Biosafety Committee and the 403 Christopher E. Mason, PhD Cornell-Weill Medical School and Alison Kriegel, PhD Medical College of 404 Wisconsin as well as public employees from Racine, WI in their partnership to this project. We would 
medRxiv preprint doi: https://doi.org/10.1101/2020.07.28.20164038; this version posted February 28, 2021. The copyright holder for this preprint (which was not certified by peer review) is the author/funder, who has granted medRxiv a license to display the preprint in perpetuity.

It is made available under a CC-BY-NC 4.0 International license .

405 like to thank Abigail Johnson, Abby Weaver, Abdel Daoud, Allison Eierman, Ben Boerigter, Clarissa 406 Tjoanda, Julia Pulokas, Julie Chen, Ryan Anderson, WIII Vuyk, Jenny Lee, Max Bobholz, Sam 407 Havlicek, Hunter Ries, Nicole Minerva, Emma Boehm, Elizabeth Brown, and Jayden Lee for their help 408 preparing and organizing supplies for POC testing. David Beebe, Nate Grubaugh, and Kristian 409 Andersen provided useful technical discussions. We thank Eli O'Connor for assistance with POC label 410 generation and template preparation. We are grateful to the study volunteers and organizations that 411 allowed us to evaluate this mobile testing strategy.

\section{Author Contributions}

414 CMN, MDR, RWW, DMD, CGS, DHO, SLO contributed to assay development and optimization. DMD, 415 MTM, RWW, CMN, MRS, AMW, MIB, KNF, MDR, LAH, OEH, RVM, CMC, SLO, MRR, TCF, TMP, 416 EDS, LMS, EKN contributed to point of care testing and PCR confirmation. CMN, MDR, DMD, DHO 417 contributed to data analysis, interpretation, and writing. JAK, DHO, SLO, HEB, TCF, MTM, AKH, LAH, $418 \mathrm{CMC}, \mathrm{KLH}, \mathrm{CBB}, \mathrm{KNF}$ contributed to logistics and organization of point of care testing. CBB, KLH 419 contributed to obtaining IRB and worked closely with the institutional biosafety committee on other 420 regulatory responsibilities. MAA, ASH, WMR contributed to providing residual SARS-CoV-2 positive 421 saliva samples and sample information from the University of Wisconsin Hospitals and Clinics. All 422 authors contributed to editing the manuscript.

\section{Regulatory oversight}

425 This work was performed under approved UW-Madison Health Sciences IRB \#2020-0855 and \#20204261142. 


\section{References}

436 1. Silverman JD, Hupert N, Washburne AD. Using influenza surveillance networks to estimate statespecific prevalence of SARS-CoV-2 in the United States. Sci Transl Med 2020, 1210.1126/scitransImed.abc1126

2. Havers FP, Reed C, Lim T, Montgomery JM, Klena JD, Hall AJ, Fry AM, Cannon DL, Chiang CF, Gibbons A, Krapiunaya I, Morales-Betoulle M, Roguski K, Rasheed MAU, Freeman B, Lester S, Mills L, Carroll DS, Owen SM, Johnson JA, Semenova V, Blackmore C, Blog D, Chai SJ, Dunn A,

446 3. Esbin MN, Whitney ON, Chong S, Maurer A, Darzacq X, Tjian R. Overcoming the bottleneck to widespread testing: a rapid review of nucleic acid testing approaches for COVID-19 detection. RNA 2020, 26:771-783. 10.1261/rna.076232.120 Hand J, Jain S, Lindquist S, Lynfield R, Pritchard S, Sokol T, Sosa L, Turabelidze G, Watkins SM, Wiesman J, Williams RW, Yendell S, Schiffer J, Thornburg NJ. Seroprevalence of Antibodies to SARS-CoV-2 in 10 Sites in the United States, March 23-May 12, 2020. JAMA Intern Med 2020, 10.1001/jamainternmed.2020.4130

452 5. Arons MM, Hatfield KM, Reddy SC, Kimball A, James A, Jacobs JR, Taylor J, Spicer K, Bardossy AC, Oakley LP, Tanwar S, Dyal JW, Harney J, Chisty Z, Bell JM, Methner M, Paul P, Carlson CM, 
medRxiv preprint doi: https://doi.org/10.1101/2020.07.28.20164038; this version posted February 28, 2021. The copyright holder for this preprint (which was not certified by peer review) is the author/funder, who has granted medRxiv a license to display the preprint in perpetuity. It is made available under a CC-BY-NC 4.0 International license .

Smith C, Page LC, Kay M, Lewis J, Montgomery P, Stone ND, Clark TA, Honein MA, Duchin JS, Jernigan JA. Presymptomatic SARS-CoV-2 Infections and Transmission in a Skilled Nursing Facility. N Engl J Med 2020, 382:2081-2090. 10.1056/NEJMoa2008457

6. Bai Y, Yao L, Wei T, Tian F, Jin DY, Chen L, Wang M. Presumed Asymptomatic Carrier Transmission of COVID-19. JAMA 2020, 323:1406-1407. 10.1001/jama.2020.2565

7. Rothe C, Schunk M, Sothmann P, Bretzel G, Froeschl G, Wallrauch C, Zimmer T, Thiel V, Janke C, Guggemos W, Seilmaier M, Drosten C, Vollmar P, Zwirglmaier K, Zange S, Wölfel R, Hoelscher M. Transmission of 2019-nCoV Infection from an Asymptomatic Contact in Germany. N Engl J Med 2020, 382:970-971. 10.1056/NEJMc2001468

8. Quicke K, Gallichote E, Sexton N, Young M, Janich A, Gahm G, Carlton EJ, Ehrhart N, Ebel GD. Longitudinal Surveillance for SARS-CoV-2 RNA Among Asymptomatic Staff in Five Colorado Skilled Nursing Facilities: Epidemiologic, Virologic and Sequence Analysis. medRxiv 2020, $10.1101 / 2020.06 .08 .20125989$

9. Furukawa NW, Brooks JT, Sobel J. Evidence Supporting Transmission of Severe Acute Respiratory Syndrome Coronavirus 2 While Presymptomatic or Asymptomatic. Emerg Infect Dis 2020, 2610.3201/eid2607.201595

10. Johansson MA, Quandelacy TM, Kada S, Prasad PV, Steele M, Brooks JT, Slayton RB, Biggerstaff M, Butler JC. SARS-CoV-2 Transmission From People Without COVID-19 Symptoms. JAMA Netw Open 2021, 4:e2035057. 10.1001/jamanetworkopen.2020.35057

11. Lavezzo E, Franchin E, Ciavarella C, Cuomo-Dannenburg G, Barzon L, Del Vecchio C, Rossi L, Manganelli R, Loregian A, Navarin N, Abate D, Sciro M, Merigliano S, De Canale E, Vanuzzo MC, Besutti V, Saluzzo F, Onelia F, Pacenti M, Parisi SG, Carretta G, Donato D, Flor L, Cocchio S, Masi G, Sperduti A, Cattarino L, Salvador R, Nicoletti M, Caldart F, Castelli G, Nieddu E, Labella B, Fava L, Drigo M, Gaythorpe KAM, Brazzale AR, Toppo S, Trevisan M, Baldo V, Donnelly CA, Ferguson NM, Dorigatti I, Crisanti A. Suppression of a SARS-CoV-2 outbreak in the Italian municipality of Vo'. Nature 2020, 584:425-429. 10.1038/s41586-020-2488-1 
medRxiv preprint doi: https://doi.org/10.1101/2020.07.28.20164038; this version posted February 28, 2021. The copyright holder for this preprint (which was not certified by peer review) is the author/funder, who has granted medRxiv a license to display the preprint in perpetuity.

It is made available under a CC-BY-NC 4.0 International license .

481

482

483

484

12. Zou L, Ruan F, Huang M, Liang L, Huang H, Hong Z, Yu J, Kang M, Song Y, Xia J, Guo Q, Song T, He J, Yen HL, Peiris M, Wu J. SARS-CoV-2 Viral Load in Upper Respiratory Specimens of Infected Patients. N Engl J Med 2020, 382:1177-1179. 10.1056/NEJMc2001737

13. Lee S, Kim T, Lee E, Lee C, Kim H, Rhee H, Park SY, Son HJ, Yu S, Park JW, Choo EJ, Park S, Loeb M, Kim TH. Clinical Course and Molecular Viral Shedding Among Asymptomatic and Symptomatic Patients With SARS-CoV-2 Infection in a Community Treatment Center in the Republic of Korea. JAMA Intern Med 2020, 180:1-6. 10.1001/jamainternmed.2020.3862

14. Mina MJ, Parker R, Larremore DB. Rethinking Covid-19 Test Sensitivity - A Strategy for Containment. N Engl J Med 2020, 383:e120. 10.1056/NEJMp2025631

15. Rivers C, Silcox C, Potter C, Franklin M, Ray R, Gill M, McClellan M. Risk Assessment and Testing Protocols for Reducing SARS-CoV-2 Transmission in K-12 Schools. Duke Margolis Center for Health Policy 2020

16. Dibner KA, Schweingruber HA, Christakis DA. Reopening K-12 Schools During the COVID-19 Pandemic: A Report From the National Academies of Sciences, Engineering, and Medicine. JAMA 2020, 324:833-834. 10.1001/jama.2020.14745

17. Notomi T, Okayama H, Masubuchi H, Yonekawa T, Watanabe K, Amino N, Hase T. Loopmediated isothermal amplification of DNA. Nucleic Acids Res 2000, 28:E63. 10.1093/nar/28.12.e63

18. Mahony J, Chong S, Bulir D, Ruyter A, Mwawasi K, Waltho D. Multiplex loop-mediated isothermal amplification (M-LAMP) assay for the detection of influenza $A / H 1, A / H 3$ and influenza $B$ can provide a specimen-to-result diagnosis in 40 min with single genome copy sensitivity. J Clin Virol 2013, 58:127-131. 10.1016/j.jcv.2013.06.006

19. McKenna JP, Cox C, Fairley DJ, Burke R, Shields MD, Watt A, Coyle PV. Loop-mediated isothermal amplification assay for rapid detection of Streptococcus agalactiae (group B streptococcus) in vaginal swabs - a proof of concept study. J Med Microbiol 2017, 66:294-300. $10.1099 / \mathrm{jmm} \cdot 0.000437$ 
medRxiv preprint doi: https://doi.org/10.1101/2020.07.28.20164038; this version posted February 28, 2021. The copyright holder for this preprint (which was not certified by peer review) is the author/funder, who has granted medRxiv a license to display the preprint in perpetuity.

It is made available under a CC-BY-NC 4.0 International license .

507 20. Gonçalves DDS, Hooker DJ, Dong Y, Baran N, Kyrylos P, Iturbe-Ormaetxe I, Simmons CP,

508 O'Neill SL. Detecting wMel Wolbachia in field-collected Aedes aegypti mosquitoes using loop509 mediated isothermal amplification (LAMP). Parasit Vectors 2019, 12:404. 10.1186/s13071-019-

$510 \quad 3666-610.1186 / s 13071-019-3666-6$

511 21. Romero Romero JL, Carver GD, Arce Johnson P, Perry KL, Thompson JR. A rapid, sensitive and 512 inexpensive method for detection of grapevine red blotch virus without tissue extraction using 513 loop-mediated isothermal amplification. Arch Virol 2019, 164:1453-1457. 10.1007/s00705-019-

22. Calvert AE, Biggerstaff BJ, Tanner NA, Lauterbach M, Lanciotti RS. Rapid colorimetric detection of Zika virus from serum and urine specimens by reverse transcription loop-mediated isothermal amplification (RT-LAMP). PLoS One 2017, 12:e0185340. 10.1371/journal.pone.0185340

23. Baek YH, Um J, Antigua KJC, Park JH, Kim Y, Oh S, Kim YI, Choi WS, Kim SG, Jeong JH, Chin BS, Nicolas HDG, Ahn JY, Shin KS, Choi YK, Park JS, Song MS. Development of a reverse transcription-loop-mediated isothermal amplification as a rapid early-detection method for novel SARS-CoV-2. Emerg Microbes Infect 2020, 9:998-1007. 10.1080/22221751.2020.1756698

24. Lamb LE, Bartolone SN, Ward E, Chancellor MB. Rapid detection of novel coronavirus/Severe Acute Respiratory Syndrome Coronavirus 2 (SARS-CoV-2) by reverse transcription-loopmediated isothermal amplification. PLoS One 2020, 15:e0234682. 10.1371/journal.pone.0234682

25. Huang WE, Lim B, Hsu CC, Xiong D, Wu W, Yu Y, Jia H, Wang Y, Zeng Y, Ji M, Chang H, Zhang X, Wang H, Cui Z. RT-LAMP for rapid diagnosis of coronavirus SARS-CoV-2. Microb Biotechnol 2020, 13:950-961. 10.1111/1751-7915.13586

26. Kitagawa Y, Orihara Y, Kawamura R, Imai K, Sakai J, Tarumoto N, Matsuoka M, Takeuchi S, Maesaki S, Maeda T. Evaluation of rapid diagnosis of novel coronavirus disease (COVID-19) using loop-mediated isothermal amplification. J Clin Virol 2020, 129:104446. 
medRxiv preprint doi: https://doi.org/10.1101/2020.07.28.20164038; this version posted February 28, 2021. The copyright holder for this preprint (which was not certified by peer review) is the author/funder, who has granted medRxiv a license to display the preprint in perpetuity.

It is made available under a CC-BY-NC 4.0 International license .

532 27. Lu R, Wu X, Wan Z, Li Y, Jin X, Zhang C. A Novel Reverse Transcription Loop-Mediated 533 Isothermal Amplification Method for Rapid Detection of SARS-CoV-2. Int J Mol Sci 2020, $534 \quad 2110.3390 /$ ijms21082826

535 28. Lu R, Wu X, Wan Z, Li Y, Zuo L, Qin J, Jin X, Zhang C. Development of a Novel Reverse 536 Transcription Loop-Mediated Isothermal Amplification Method for Rapid Detection of SARS-CoV2. Virol Sin 2020, 35:344-347. 10.1007/s12250-020-00218-1 10.1007/s12250-020-00218-1

29. Yan C, Cui J, Huang L, Du B, Chen L, Xue G, Li S, Zhang W, Zhao L, Sun Y, Yao H, Li N, Zhao H, Feng Y, Liu S, Zhang Q, Liu D, Yuan J. Rapid and visual detection of 2019 novel coronavirus

30. Azzi L, Carcano G, Gianfagna F, Grossi P, Gasperina DD, Genoni A, Fasano M, Sessa F,

Tettamanti L, Carinci F, Maurino V, Rossi A, Tagliabue A, Baj A. Saliva is a reliable tool to detect SARS-CoV-2. J Infect 2020, 81:e45-e50. 10.1016/j.jinf.2020.04.005

31. Nagura-Ikeda M, Imai K, Tabata S, Miyoshi K, Murahara N, Mizuno T, Horiuchi M, Kato K, Imoto Y, Iwata M, Mimura S, Ito T, Tamura K, Kato Y. Clinical Evaluation of Self-Collected Saliva by Quantitative Reverse Transcription-PCR (RT-qPCR), Direct RT-qPCR, Reverse TranscriptionLoop-Mediated Isothermal Amplification, and a Rapid Antigen Test To Diagnose COVID-19. J Clin

32. Wyllie AL, Fournier J, Casanovas-Massana A, Campbell M, Tokuyama M, Vijayakumar P, Warren JL, Geng B, Muenker MC, Moore AJ, Vogels CBF, Petrone ME, Ott IM, Lu P, Venkataraman A, Lu-Culligan A, Klein J, Earnest R, Simonov M, Datta R, Handoko R, Naushad N, Sewanan LR, Valdez J, White EB, Lapidus S, Kalinich CC, Jiang X, Kim DJ, Kudo E, Linehan M, Mao T, Moriyama M, Oh JE, Park A, Silva J, Song E, Takahashi T, Taura M, Weizman OE, Wong P, Yang Y, Bermejo S, Odio CD, Omer SB, Dela Cruz CS, Farhadian S, Martinello RA, Iwasaki A, Grubaugh ND, Ko AI. Saliva or Nasopharyngeal Swab Specimens for Detection of SARS-CoV-2. N Engl J Med 2020, 383:1283-1286. 10.1056/NEJMc2016359 
medRxiv preprint doi: https://doi.org/10.1101/2020.07.28.20164038; this version posted February 28, 2021. The copyright holder for this preprint (which was not certified by peer review) is the author/funder, who has granted medRxiv a license to display the preprint in perpetuity.

It is made available under a CC-BY-NC 4.0 International license .

558

33. To KK, Tsang OT, Yip CC, Chan KH, Wu TC, Chan JM, Leung WS, Chik TS, Choi CY, Kandamby DH, Lung DC, Tam AR, Poon RW, Fung AY, Hung IF, Cheng VC, Chan JF, Yuen KY. Consistent Detection of 2019 Novel Coronavirus in Saliva. Clin Infect Dis 2020, 71:841-843. $10.1093 /$ cid/ciaa149

34. Yokota I, Shane PY, Okada K, Unoki Y, Yang Y, Inao T, Sakamaki K, Iwasaki S, Hayasaka K, Sugita J, Nishida M, Fujisawa S, Teshima T. Mass screening of asymptomatic persons for SARSCoV-2 using saliva. Clin Infect Dis 2020, 10.1093/cid/ciaa1388

35. Dudley DM, Newman CM, Weiler AM, Ramuta MD, Shortreed CG, Heffron AS, Accola MA, Rehrauer WM, Friedrich TC, O'Connor DH. Optimizing direct RT-LAMP to detect transmissible SARS-CoV-2 from primary nasopharyngeal swab samples. PLoS One 2020, 15:e0244882. 10.1371/journal.pone.0244882

36. Ott IM, Strine MS, Watkins AE, Boot M, Kalinich CC, Harden CA, Vogels CBF, CasanovasMassana A, Moore AJ, Muenker MC, Nakahata M, Tokuyama M, Nelson A, Fournier J, Bermejo S, Campbell M, Datta R, Dela Cruz CS, Farhadian SF, Ko Al, Iwasaki A, Grubaugh ND, Wilen CB, Wyllie AL. Simply saliva: stability of SARS-CoV-2 detection negates the need for expensive collection devices. medRxiv 2020, 10.1101/2020.08.03.20165233

37. Kim YI, Casel MAB, Kim SM, Kim SG, Park SJ, Kim EH, Jeong HW, Poo H, Choi YK. Development of severe acute respiratory syndrome coronavirus 2 (SARS-CoV-2) thermal inactivation method with preservation of diagnostic sensitivity. J Microbiol 2020, 58:886-891. $10.1007 / \mathrm{s} 12275-020-0335-6$ 10.1007/s12275-020-0335-6

38. Lalli MA, Langmade SJ, Chen X, Fronick CC, Sawyer CS, Burcea LC, Wilkinson MN, Fulton RS, Heinz M, Buchser WJ, Head RD, Mitra RD, Milbrandt J. Rapid and extraction-free detection of SARS-CoV-2 from saliva with colorimetric LAMP. medRxiv 2020, 10.1101/2020.05.07.20093542

39. Broughton JP, Deng X, Yu G, Fasching CL, Servellita V, Singh J, Miao X, Streithorst JA, Granados A, Sotomayor-Gonzalez A, Zorn K, Gopez A, Hsu E, Gu W, Miller S, Pan CY, Guevara H, Wadford DA, Chen JS, Chiu CY. CRISPR-Cas12-based detection of SARS-CoV-2. Nat Biotechnol 2020, 38:870-874. 10.1038/s41587-020-0513-4 
medRxiv preprint doi: https://doi.org/10.1101/2020.07.28.20164038; this version posted February 28, 2021. The copyright holder for this preprint (which was not certified by peer review) is the author/funder, who has granted medRxiv a license to display the preprint in perpetuity.

It is made available under a CC-BY-NC 4.0 International license .

40. Color Genomics. SARS-CoV-2 LAMP Diagnostic Assay. 2020. https://www.color.com/wpcontent/uploads/2020/05/LAMP-Diagnostic-Assay.pdf.

41. Humphrey SP, Williamson RT. A review of saliva: normal composition, flow, and function. J Prosthet Dent 2001, 85:162-169. 10.1067/mpr.2001.113778

42. Tanaka M, Masuda M. Concentration and individual variation of inorganic ions in unstimulated whole saliva. Kokubyo Gakkai Zasshi 2000, 67:46-51. 10.5357/koubyou.67.46

43. Varga G. Physiology of the salivary glands. Surgery (Oxford) 2012, 30:578-583. https://doi.org/10.1016/j.mpsur.2012.09.010

44. Public Health Madison and Dane County. Weekly COVID-19 Core Data by Date. 2021. https://www.publichealthmdc.com/coronavirus/forward-dane/data.

45. University of Wisconsin-Madison. COVID-19 Response Dashboard 2020. 2021. https://covidresponse.wisc.edu/dashboard-2020/.

46. Howson ELA, Kidd SP, Armson B, Goring A, Sawyer J, Cassar C, Cross D, Lewis T, Hockey J, Rivers S, Cawthraw S, Banyard A, Anderson P, Rahou S, Andreou M, Morant N, Clark D, Walsh C, Laxman S, Houghton R, Slater-Jefferies J, Costello P, Brown I, Cortes N, Godfrey KM, Fowler VL. Preliminary optimisation of a simplified sample preparation method to permit direct detection of SARS-CoV-2 within saliva samples using reverse-transcription loop-mediated isothermal amplification (RT-LAMP). J Virol Methods 2021, 289:114048. 10.1016/j.jviromet.2020.114048

47. Janíková M, Hodosy J, Boor P, Klempa B, Celec P. Loop-mediated isothermal amplification for the detection of SARS-CoV-2 in saliva. Microb Biotechnol 2021, 14:307-316. 10.1111/17517915.13737

48. Diaz L, Johnson BE, Jenkins DM. Real-time optical analysis of a colorimetric LAMP assay for SARS-CoV-2 in saliva with a handheld instrument improves accuracy compared to endpoint assessment. medRxiv 2021, https://doi.org/10.1101/2021.01.13.21249412

49. Brown TA, Schaefer KS, Tsang A, Yi HA, Grimm JB, Lemire AL, Jradi FM, Kim C, McGowan K, Ritola K. Direct detection of SARS-CoV-2 RNA using high-contrast pH-sensitive dyes. medRxiv 2021, 2020.12. 26.20248878. https://doi.org/10.1101/2020.12.26.20248878 
medRxiv preprint doi: https://doi.org/10.1101/2020.07.28.20164038; this version posted February 28, 2021. The copyright holder for this preprint (which was not certified by peer review) is the author/funder, who has granted medRxiv a license to display the preprint in perpetuity.

It is made available under a CC-BY-NC 4.0 International license .

612 50. Yang Q, Meyerson NR, Clark SK, Paige CL, Fattor WT, Gilchrist AR, Barbachano-Guerrero A, 613 Healy BG, Worden-Sapper ER, Wu SS. Saliva TwoStep for rapid detection of asymptomatic SARS-CoV-2 carriers. medRxiv 2021, 2020.07. 16.20150250. https://doi.org/10.1101/2020.07.16.20150250

616 51. US Food and Drug Administration. COVID-19 Update: FDA Authorizes First Diagnostic Test

52. Pilarowski G, Lebel P, Sunshine S, Liu J, Crawford E, Marquez C, Rubio L, Chamie G, Martinez J,

Peng J, Black D, Wu W, Pak J, Laurie MT, Jones D, Miller S, Jacobo J, Rojas S, Rojas S,

53. Prince-Guerra JL, Almendares O, Nolen LD, Gunn JKL, Dale AP, Buono SA, Deutsch-Feldman

M, Suppiah S, Hao L, Zeng Y, Stevens VA, Knipe K, Pompey J, Atherstone C, Bui DP, Powell T, Tamin A, Harcourt JL, Shewmaker PL, Medrzycki M, Wong P, Jain S, Tejada-Strop A, Rogers S, Emery B, Wang H, Petway M, Bohannon C, Folster JM, MacNeil A, Salerno R, Kuhnert-Tallman W, Tate JE, Thornburg NJ, Kirking HL, Sheiban K, Kudrna J, Cullen T, Komatsu KK, Villanueva JM, Rose DA, Neatherlin JC, Anderson M, Rota PA, Honein MA, Bower WA. Evaluation of Abbott BinaxNOW Rapid Antigen Test for SARS-CoV-2 Infection at Two Community-Based Testing Sites - Pima County, Arizona, November 3-17, 2020. MMWR Morb Mortal Wkly Rep 2021, 70:100-105. 10.15585/mmwr.mm7003e3

54. Pray IW, Ford L, Cole D, Lee C, Bigouette JP, Abedi GR, Bushman D, Delahoy MJ, Currie D, Cherney B, Kirby M, Fajardo G, Caudill M, Langolf K, Kahrs J, Kelly P, Pitts C, Lim A, Aulik N, Tamin A, Harcourt JL, Queen K, Zhang J, Whitaker B, Browne H, Medrzycki M, Shewmaker P, Folster J, Bankamp B, Bowen MD, Thornburg NJ, Goffard K, Limbago B, Bateman A, Tate JE, Gieryn D, Kirking HL, Westergaard R, Killerby M. Performance of an Antigen-Based Test for 
medRxiv preprint doi: https://doi.org/10.1101/2020.07.28.20164038; this version posted February 28, 2021. The copyright holder for this preprint (which was not certified by peer review) is the author/funder, who has granted medRxiv a license to display the preprint in perpetuity.

It is made available under a CC-BY-NC 4.0 International license .

Asymptomatic and Symptomatic SARS-CoV-2 Testing at Two University Campuses - Wisconsin, September-October 2020. MMWR Morb Mortal Wkly Rep 2021, 69:1642-1647.

$$
\text { 10.15585/mmwr.mm695152a3 }
$$

55. US Food and Drug Administration. BinaxNOW COVID-19 Ag Card. 2020. https://www.fda.gov/media/141570/download.

56. Alekseenko A, Barrett D, Pareja-Sanchez Y, Howard RJ, Strandback E, Ampah-Korsah H, Rovšnik U, Zuniga-Veliz S, Klenov A, Malloo J, Ye S, Liu X, Reinius B, Elsässer SJ, Nyman T, Sandh G, Yin X, Pelechano V. Direct detection of SARS-CoV-2 using non-commercial RT-LAMP reagents on heat-inactivated samples. Sci Rep 2021, 11:1820. 10.1038/s41598-020-80352-8 $10.1038 / \mathrm{s} 41598-020-80352-8$

57. Simon S. How A Chicago Dad Developed A Coronavirus Testing Program For His Son's School. National Public Radio. 2020. https://www.npr.org/2020/09/26/917185895/how-a-chicago-daddeveloped-a-coronavirus-testing-program-for-his-sons-school.

58. Chappell K. Coronavirus Saliva Screening Program Expands at Suburban Schools. NBC Chicago, 2020. https://www.nbcchicago.com/news/local/coronavirus-saliva-screening-program-expands-atsuburban-schools/2374812/

59. Lee EC, Wada NI, Grabowski MK, Gurley ES, Lessler J. The engines of SARS-CoV-2 spread. Science 2020, 370:406-407. 10.1126/science.abd8755

60. Ryan S. 5 Big Ten football takeaways after Week 6 , including the messy league rules of playing during COVID-19 and who has a shot at the championship. Chicago Tribune, 2020. https://www.chicagotribune.com/sports/college/ct-cb-big-ten-takeaways-ohio-state-covid-1920201130-zjxnilkmujhtrop53ytthg7i7i-story.html

61. Kissler SM, Fauver JR, Mack C, Tai C, Shiue KY, Kalinich CC, Jednak S, Ott IM, Vogels CBF, Wohlgemuth J. Viral dynamics of SARS-CoV-2 infection and the predictive value of repeat testing. medRxiv 2020, https://doi.org/10.1101/2020.10.21.20217042 
medRxiv preprint doi: https://doi.org/10.1101/2020.07.28.20164038; this version posted February 28, 2021. The copyright holder for this preprint (which was not certified by peer review) is the author/funder, who has granted medRxiv a license to display the preprint in perpetuity.

It is made available under a CC-BY-NC 4.0 International license .

62. Buchanan L, Gamio L, Leatherby L, Stein R, Triebert C. Inside the White House Event Now Under Covid-19 Scrutiny. The New York Times, 2020. https://www.nytimes.com/interactive/2020/10/03/us/rose-garden-event-covid.html

\section{Figure legends}

Figure 1: Point-of-care RT-LAMP SARS-CoV-2 testing workflow. Steps 1-5. Saliva sample preparation. Steps 6-7. RT-LAMP reagent preparation. Steps 8-10. RT-LAMP reactions and results interpretation. A reaction color change from pink/orange to yellow after 30 minutes in at least 1 of 2 sample replicates was scored as positive. Figure was created using BioRender.com.

Figure 2: Detection of SARS-CoV-2 in contrived saliva samples by direct RT-LAMP. A. Initial limit of detection (LOD) assessment with contrived saliva samples from 3 volunteers (S1, S2, S3). RT-LAMP reactions determined to be negative are pink and those determined to be positive are yellow. Quantitative RT-PCR vRNA loads are presented as copies/ $\mu$ l above the replicates for each sample. B. Bar graph showing an expanded assessment of RT-LAMP LOD for 22 additional contrived saliva samples (S4-S25). Gamma-irradiated SARS-CoV-2 (irSARS-CoV-2) vRNA load is shown as copies/ $\mu \mathrm{l}$ on the x-axis, number of samples positive in 2 (black), 1 (dark gray), or 0 (light gray) replicates is shown on the y-axis. 
medRxiv preprint doi: https://doi.org/10.1101/2020.07.28.20164038; this version posted February 28, 2021. The copyright holder for this preprint (which was not certified by peer review) is the author/funder, who has granted medRxiv a license to display the preprint in perpetuity.

It is made available under a CC-BY-NC 4.0 International license .

690 Figure 3: Detection of SARS-CoV-2 in 38 clinical saliva specimens by direct RT-LAMP. The vRNA

691 load of each clinical sample is plotted on the x-axis relative to the in-house CDC N1 qRT-PCR assay

692 cycle threshold (Ct) on the y-axis. Black, dark gray, and light gray indicate 2, 1, and 0 positive replicates

693 respectively.

694

695

696

697

698

699

700

701

702 Table 1. RT-LAMP N-gene primers

\begin{tabular}{|c|c|c|}
\hline Primer & Sequence $5^{\prime}->3^{\prime}$ & Concentration \\
\hline Outer forward primer (F3) & AACACAAGCTTTCGGCAG & $0.2 \mathrm{uM}$ \\
\hline Outer backward primer (B3) & GAAATTTGGATCTTTGTCATCC & $0.2 \mathrm{uM}$ \\
\hline Forward inner primer (FIP) & TGCGGCCAATGTTTGTAATCAGCCAAGGAAATTTTGGGGAC & $1.6 \mathrm{uM}$ \\
\hline Backward inner primer (BIP) & CGCATTGGCATGGAAGTCACTTTGATGGCACCTGTGTAG & $1.6 \mathrm{uM}$ \\
\hline Loop forward primer (LF) & TTCCTTGTCTGATTAGTTC & $0.8 \mathrm{uM}$ \\
\hline Loop backward primer (LB) & ACCTTCGGGAACGTGGTT & $0.8 \mathrm{MM}$ \\
\hline
\end{tabular}


medRxiv preprint doi: https://doi.org/10.1101/2020.07.28.20164038; this version posted February 28, 2021. The copyright holder for this preprint (which was not certified by peer review) is the author/funder, who has granted medRxiv a license to display the preprint in perpetuity.

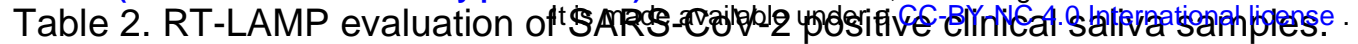

\begin{tabular}{|c|c|c|c|c|c|c|c|}
\hline Sample & Ct (N1 assay) & $\begin{array}{c}\text { Positive by } \\
\text { RT-LAMP }\end{array}$ & $\begin{array}{l}\text { vRNA load } \\
\text { (copies/ } \mu \mathrm{l} \text { ) }\end{array}$ & Sample & Ct (N1 assay) & $\begin{array}{c}\text { Positive by } \\
\text { RT-LAMP }\end{array}$ & 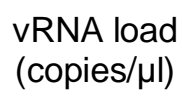 \\
\hline UWHC1 & 27.65 & $0 / 2$ & $3.25 \times 10^{2}$ & UWHC20 & 25.80 & $2 / 2$ & $9.48 \times 10^{2}$ \\
\hline UWHC2 & 32.7 & $0 / 2$ & 10.9 & UWHC21 & 20.18 & $2 / 2$ & $4.40 \times 10^{4}$ \\
\hline UWHC3 & 20.98 & $2 / 2$ & $5.17 \times 10^{4}$ & UWHC22 & 28.92 & $0 / 2$ & $1.13 \times 10^{2}$ \\
\hline UWHC4 & 24.07 & $2 / 2$ & $3.57 \times 10^{3}$ & UWHC23 & 21.26 & $2 / 2$ & $2.10 \times 10^{4}$ \\
\hline UWHC5 & 26.53 & $2 / 2$ & $6.81 \times 10^{2}$ & UWHC24 & 29.92 & $0 / 2$ & 57.2 \\
\hline UWHC6 & 30.85 & $1 / 2$ & 37.4 & UWHC25 & 36.71 & $0 / 2$ & $0.796^{*}$ \\
\hline UWHC7 & 36.96 & $0 / 2$ & 0.701 & UWHC26 & 25.96 & $2 / 2$ & $1.31 \times 10^{2}$ \\
\hline UWHC8 & 26.28 & $1 / 2$ & $8.10 \times 10^{2}$ & UWHC27 & 29.99 & $0 / 2$ & 54.1 \\
\hline UWHC9 & 37.59 & $0 / 2$ & 0.402 & UWHC28 & 24.34 & $2 / 2$ & $2.58 \times 10^{3}$ \\
\hline UWHC10 & 24.01 & $2 / 2$ & $3.72 \times 10^{3}$ & UWHC29 & 20.55 & $2 / 2$ & $4.72 \times 10^{4}$ \\
\hline UWHC11 & 22.39 & $2 / 2$ & $1.10 \times 10^{4}$ & UWHC30 & 33.18 & $0 / 2$ & 7.89 \\
\hline UWHC12 & 35.46 & $0 / 2$ & 1.75 & UWHC31 & 22.87 & $2 / 2$ & $9.57 \times 10^{3}$ \\
\hline UWHC13 & 36.09 & $0 / 2$ & 1.14 & UWHC32 & 23.07 & $2 / 2$ & $8.33 \times 10^{3}$ \\
\hline UWHC14 & 23.11 & $2 / 2$ & $5.96 \times 10^{3}$ & UWHC33 & 26.85 & $2 / 2$ & $6.20 \times 10^{2}$ \\
\hline UWHC15 & 23.38 & $2 / 2$ & $4.95 \times 10^{3}$ & UWHC34 & 20.33 & $0 / 2$ & $5.49 \times 10^{4}$ \\
\hline UWHC16 & 33.86 & $0 / 2$ & 3.99 & UWHC35 & 23 & $2 / 2$ & $8.88 \times 10^{3}$ \\
\hline UWHC17 & $\mathrm{n} / \mathrm{a}$ & $0 / 2$ & 0 & UWHC36 & 32.26 & $0 / 2$ & $14.9^{\star}$ \\
\hline UWHC18 & 23.02 & $2 / 2$ & $6.34 \times 10^{3}$ & UWHC37 & 33.94 & $0 / 2$ & 4.33 \\
\hline UWHC19 & 37.31 & $0 / 2$ & 0.612 & UWHC38 & 25.96 & $2 / 2$ & $1.74 \times 10^{3}$ \\
\hline
\end{tabular}

${ }^{*}$ Sample only positive in one qRT-PCR replicate. 
medRxiv preprint doi: https://doi.org/10.1101/2020.07.28.20164038; this version posted February 28, 2021. The copyright holder for this preprint (which was not certified by peer review) is the author/funder, who has granted medRxiv a license to display the preprint in perpetuity.

It is made available under a CC-BY-NC 4.0 International license.

Table 3. RT-LAMP results for 10- and 100-fold dilutions of 13 SARS-CoV-2-positive samples from UWHC.

\begin{tabular}{cccc}
\hline Sample & $1: 10$ dilution result & $1: 100$ dilution result & Undiluted vRNA load (copies/ $/$ l) \\
\hline UWHC1 & $1 / 2$ & $0 / 2$ & $3.25 \times 10^{2}$ \\
UWHC2 & $0 / 2$ & $0 / 2$ & 10.9 \\
UWHC3 & $2 / 2$ & $2 / 2$ & $5.17 \times 10^{4}$ \\
UWHC4 & $2 / 2$ & $2 / 2$ & $3.57 \times 10^{3}$ \\
UWHC5 & $1 / 2$ & $0 / 2$ & $6.81 \times 10^{2}$ \\
UWHC6 & $0 / 2$ & $0 / 2$ & 37.4 \\
UWHC7 & $0 / 2$ & $0 / 2$ & 0.701 \\
UWHC8 & $1 / 2$ & $0 / 2$ & $8.10 \times 10^{2}$ \\
UWHC9 & $0 / 2$ & $0 / 2$ & 0.402 \\
UWHC10 & $2 / 2$ & $0 / 2$ & $3.72 \times 10^{3}$ \\
UWHC11 & $2 / 2$ & $1 / 2$ & $1.10 \times 10^{4}$ \\
UWHC12 & $0 / 2$ & $0 / 2$ & 1.75 \\
UWHC13 & $0 / 2$ & $0 / 2$ & 1.14 \\
\hline
\end{tabular}


medRxiv preprint doi: https://doi.org/10.1101/2020.07.28.20164038; this version posted February 28, 2021. The copyright holder for this preprint (which was not certified by peer review) is the author/funder, who has granted medRxiv a license to display the preprint in perpetuity.

It is made available under a CC-BY-NC 4.0 International license.

Table 4. Samples identified as potentially positive for SARS-CoV-2 by RT-LAMP during point-of-need testing.

\begin{tabular}{|c|c|}
\hline RT-LAMP-positive sample & qRT-PCR viral load copies/ $\mu$ l \\
\hline POC1 & 8.53 \\
\hline POC2 & $2.15 \times 10^{4}$ \\
\hline POC3 & neg \\
\hline POC4 & neg \\
\hline POC5 & neg \\
\hline POC6 & neg \\
\hline POC7 & $3.62 \times 10^{5}$ \\
\hline POC8 & neg \\
\hline POC9 & $n / a^{*}$ \\
\hline POC10 & $2.12 \times 10^{3}$ \\
\hline POC11 & neg \\
\hline POC12 & $1.04 \times 10^{3}$ \\
\hline POC13 & $2.06 \times 10^{2}$ \\
\hline POC14 & neg \\
\hline POC15 & 52.8 \\
\hline POC16 & $6.02 \times 10^{2}$ \\
\hline POC17 & 87.3 \\
\hline POC18 & $1.17 \times 10^{3}$ \\
\hline POC19 & neg \\
\hline POC20 & $1.38 \times 10^{2}$ \\
\hline POC21 & $4.07 \times 10^{2}$ \\
\hline
\end{tabular}

*Volunteer did not consent to follow-up testing. 


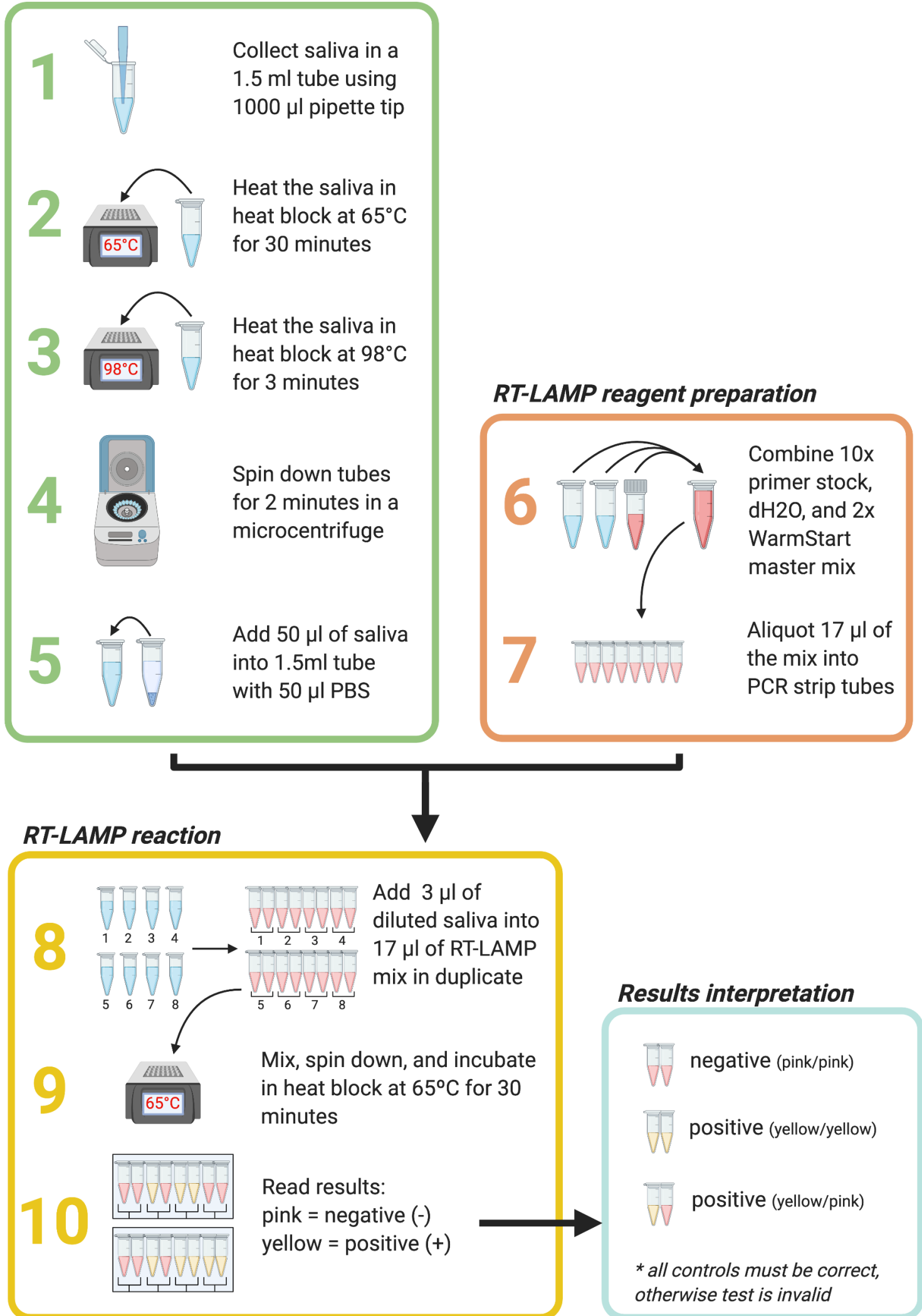




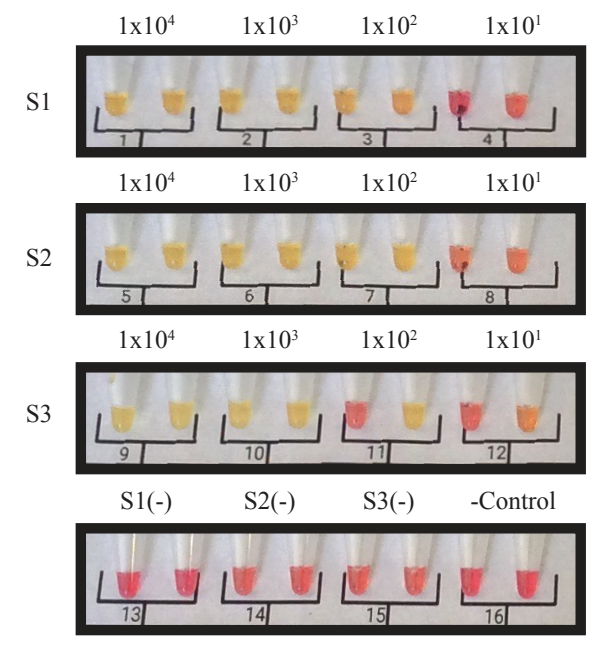

+ Control

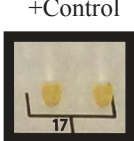

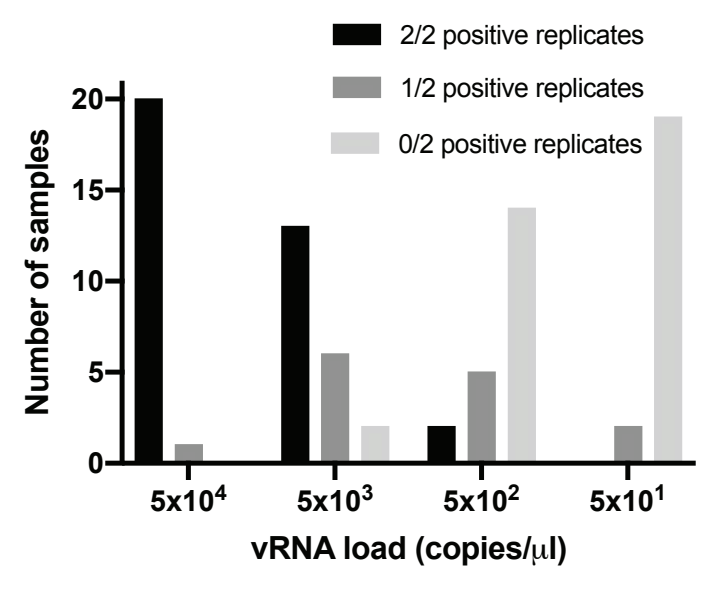


- $2 / 2$ positive replicates

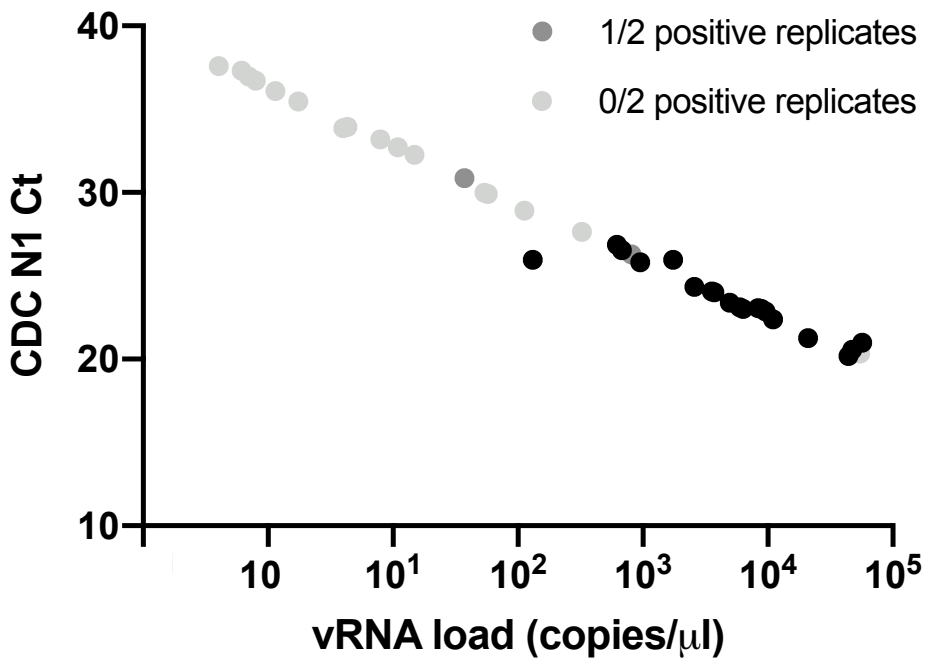

